\title{
Water Deficits and Environmental Factors Affect Photosynthesis in Leaves of Cucumber (Cucumis sativus)
}

\author{
Abdul K. Janoudi', Irvin E. Widders ${ }^{2}$, and James A. Flore \\ Department of Horticulture, Michigan State University, East Lansing, MI 48824 \\ Additional index words. gas exchange, stomatal conductance, translocate sugars, water stress
}

\begin{abstract}
Cucumber plants were cultured in a greenhouse and subjected to either well-watered or water deficit conditions that reduced leaf water potential to-0.6 MPa. Leaf gas exchange measurements were conducted using an open gas exchange system. Carbon dioxide assimilation $(A)$ attained saturation at a photon flux density (PFD) of $1000 \mu \mathrm{mol} \cdot \mathrm{m}^{-2} \cdot \mathrm{s}^{-1}(400-700$ $\mathrm{nm})$. There were no significant differences in $A$ at ambient temperatures between 16 and 34C. Water use efficiency decreased rapidly with increasing vapor-pressure deficits to $2.5 \mathrm{kPa}$. Water stressed plants had lower stomata1 conductances and $\mathrm{CO}_{2}$ assimilation rates. The decrease in $A$ was only partially due to stomatal closure. The $A$ vs. intercellular $\mathrm{CO}$ $\left(C_{i}\right)$ relationship for stressed leaves revealed a change in the $C O$, compensation point, and that nonstomatal factors were contributing to the decrease in $A$ in stressed plants. Thus, feedback inhibition of $A$ may have occurred through photoassimilate accumulation. The concentrations of sucrose and raffinose were higher, and the concentration of stachyose was lower in leaves of stressed than of well-watered plants.
\end{abstract}

Plant water deficits result in low photosynthetic rates in leaves (Ackerson and Hebert, 1981; Huck et al., 1983; Karamanos et al., 1982). The cause of the decrease in photosynthesis with the onset of water stress is still not completely understood. Under water stress conditions, low $\mathrm{CO}_{2}$ fixation rates have been attributed to low intercellular $\mathrm{CO}_{2}\left(\mathrm{C}_{\mathrm{i}}\right.$ levels (Raschke and Hedrich, 1985; Sharkey and Seemann, 1989), accumulation of assimilates (Ackerson, 1980; Azcon-Bieto, 1983), localized low-water potentials in the mesophyll (Schulze and Kuppers, 1979), and decreased ribulose-1,5-bisphosphate carboxylase activity ( $\mathrm{Vu}$ and Yelenosky, 1988).

Stomata1 closure is in part responsible for reductions in the photosynthetic rate. Stomatal conductance decreases in response to turgor loss upon exposure to low soil-water potentials (Blackman and Davies, 1985) and low humidity (Schulze and Kuppers, 1979). An increase in abscisic acid (ABA) concentration within leaftissue under water-deficit conditions stimulates rapid ion efflux from guard cells, thus leading to stomatal closure (Ackerson, 1980; Raschke and Hedrich, 1985).

Cucumber plants have a high water requirement (Loomis and Crandall, 1977) and are considered to be sensitive to drought stress. Prolonged exposure to low soil moisture, due to a lack of rainfall or irrigation, has been shown to reduce significantly fruit yield and quality (Doss et al., 1977; Elkner, 1985). Transient water deficits are also observed in cucumber plants when transpiration rates exceed the rate of water uptake by the root system, such as at midday. Plant water deficits are evidenced by leaf wilting, closure of stomates, and, ultimately, a reduction in photosynthetic rate (Ackerson and Herbert, 1981; Genty et al., 1987).

The objective of this study was to investigate the effects of plant water status on gas exchange rates in cucumber leaves over a range of light, temperature, and vapor-pressure deficit regimes. We also

\footnotetext{
Received for publication 31 Jan. 1992. Accepted for publication 30 Oct. 1992. The cost of publishing this paper was defrayed in part by the payment of page charges. Under postal regulations, this paper therefore must be hereby marked advertisement solely to indicate this fact.

${ }^{1}$ Visiting Research Associate, Plant Research Laboratory, Michigan State Univ., East Lansing, MI 48824.

${ }^{2}$ Associate Professor. To whom reprint requests should be addressed.
}

evaluated the recovery of photosynthetic activity following relief of water stress.

\section{Materials and Methods}

Plant material. Greenhouse experiments were conducted from June to Aug. 1986 and 1987. Seeds of the pickling cucumber inbred lines Gy 14 and M 21 were sown in a 1:1 peat (Baccto Professional Mix, Michigan Peat Co., Houston) to sandy loam soil mixture in 11-liter plastic containers. Plants were drip-irrigated daily to saturation during vegetative development and fertilized twice weekly using Peter's 20N-8.8P-16.6K soluble fertilizer at $0.2 \mathrm{~g} \cdot$ liter $^{-1}$. Pistillate flowers were hand-pollinated between $10 \mathrm{AM}$ and noon on the days the flowers opened. Day/night temperatures were maintained at $\approx 30 / 20 \pm 5 \mathrm{C}$, and no supplemental lighting was provided.

Cucumber plants were also cultured in a field environment during June through Aug. 1987. Seeds were planted into 11-liter plastic containers filled with a fertile Brookston loam (fine-loamy, mixed, mesic, typic Argiaquolls) soil. The containers were buried in the soil at a field cucumber production site at the Michigan State Univ. Horticulture Research and Teaching Center in East Lansing. The containers were arranged in four rows, $90 \mathrm{~cm}$ apart. Only one plant was allowed to develop per container. Two irrigations during the vegetative stage supplemented natural rainfall.

Water regime. Water deficit treatments were induced by withholding water from container-grown plants bearing two to three fruits for 3 or 4 days until the predawn leaf water potential had reached $-0.6 \mathrm{MPa}$ (measured by Scholander pressure chamber). Plants used in studying recovery of photosynthetic activity were rewatered $12 \mathrm{~h}$ before gas exchange measurements were made. Control plants were watered daily.

Leaf gas exchange measurements. Gas exchange responses to light, temperature, and $\mathrm{CO}_{2}$ concentration on the fifth leaf from the shoot apex were determined using an open gas exchange system previously described by Sams and Flore (1982). Each leaf was

Abbreviations: A, carbon dioxide assimilation; $\mathrm{g}_{s}$, stomata1 conductance; PFD, photon flux density; RuBPcase, ribulosebisphosphate carboxylase; VPD, vaporpressure deficit; WUE, water use efficiency. 
enclosed in a $20 \times 10 \times 10 \mathrm{~cm}$ deep controlled environment chamber. Leaves were allowed to equilibrate with the microenvironment of the chamber for $2 \mathrm{~h}$ before gas exchange measurements were initiated.

To determine the light response curve, gas exchange measurements were made in a growth chamber at several levels of photosynthetic photon flux density (PFD) beginning at a flux density of $1800 \mu \mathrm{mol} \cdot \mathrm{m}^{-2} \cdot \mathrm{s}^{-1}$ and incrementally decreasing to total darkness. Ambient $\mathrm{CO}_{2}$ concentration was maintained at $345 \pm 5 \mu \mathrm{l} \cdot \mathrm{liter}^{-1}$ at $25 \pm 0.5 \mathrm{C}$. The temperature response curve was determined by raising leaf temperature from $\approx 10$ to $40 \mathrm{C}$ in increments of 3 to $5 \mathrm{C}$. Vapor-pressure deficit (VPD) was maintained at $<1.5 \mathrm{kPa}$ up to 30C, above which VPD increased rapidly. $\mathrm{CO}_{2}$-assimilation rate (A) response to $\mathrm{C}_{\mathrm{i}}$ was determined under differential water availability conditions by exposing leaves to ambient $\mathrm{CO}_{2}$ levels from zero to $750 \mu \mathrm{l} \cdot$ liter $^{-1}$.

A portable open system LCA-2 analyzer (Analytical Development Corp., Hodesdon, England) was used for measurement of $A$, PFD, relative humidity, and leaf temperature in the greenhouse or field. The analyzer was operated in a differential mode with an air flow rate of $600 \mathrm{~cm}^{3} \cdot \mathrm{min}^{-1}$. Stomatal conductance $\left(\mathrm{g}_{\mathrm{s}}\right)$, transpiration rate $(\mathrm{E})$, and VPD were calculated using a computer program developed by Moon and Flore (1986). All measurements were made under sunlight between 10:30 AM and 12:30 PM. Ambient $\mathrm{CO}_{2}$ levels were between 325 and $348 \mu \mathrm{l} \cdot$ liter $^{-1}$. Measurements were made on the fourth and sixth leaves from the shoot apex of each plant. The experiment design was a randomized complete block with three replications and two plants per plot.

Leaf sugar determinations. Lamina tissue from the fourth or fifth leaf from the shoot apex was freeze-dried for $24 \mathrm{~h}$ and ground finely with a mortar and pestle. Soluble sugars were extracted from tissue $(0.2 \mathrm{~g})$ with $80 \%$ ethanol at $70 \mathrm{C}$ for $1 \mathrm{~h}$. The extract was filtered through Whatman no. 1 filter paper and the ethanol evaporated. The residue was redissolved in $25 \mathrm{ml}$ of deionized water and an aliquot of the resultant solution filtered through a 0.45 $\mu \mathrm{m}$ Millex-HA filter unit (Millipore; Bedford, Mass.). Sugars and sugar alcohols were assayed using a Dionex Carbopac PA 1 anion exchange separation column (Dionex; Sunnyvale, Calif.) with a Dionex series 4000i high performance ion chromatography mod-

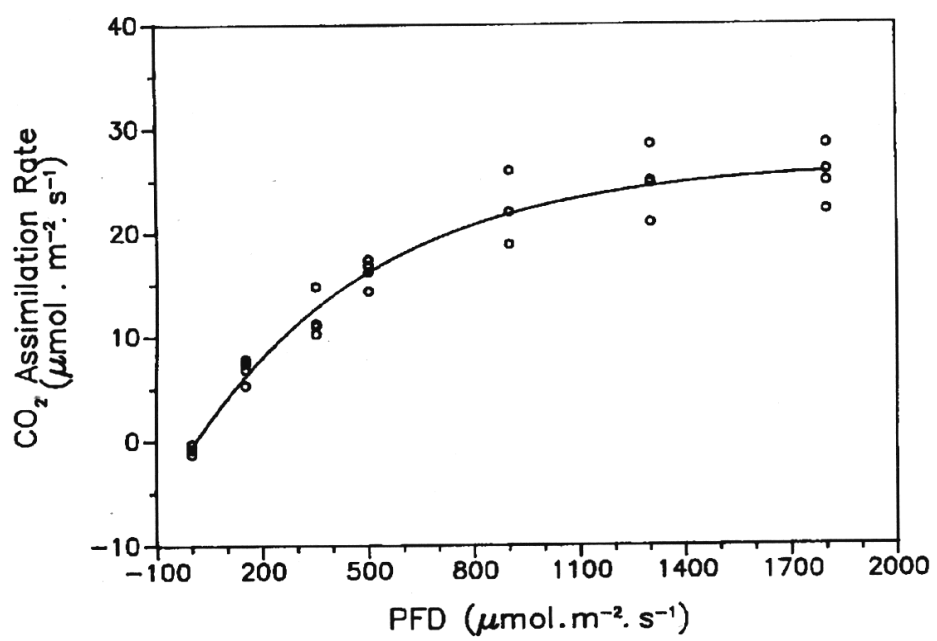

Fig. 1. Effects of increasing photon flux density on the photosynthetic rate of the fifth leaf from the shoot apex of greenhouse-grown cucumber plants. Ambient temperature and $\mathrm{CO}_{2}$ concentration were maintained at $25 \mathrm{C}$ and $350 \mathrm{ppm}$, respectively. Data points represent individual measurements on leaves from different plants. The curve was fitted to data according to the equation: $Y=B_{1} \times$ $\operatorname{Exp}\left(B_{2} \times X\right)+B_{3}$, where $B_{n}$ are estimated variables; $r^{2}=0.96$. ule and a pulsed amperometric detector with a gold electrode. A 0.1 $\mathrm{M} \mathrm{NaOH}$ solution was used as the eluant.

\section{Results}

The $A$ rate reached saturation at a PFD of $\approx 1000 \mu \mathrm{mol} \cdot \mathrm{m}^{-2} \cdot \mathrm{s}^{-1}$ (Fig. 1). Subsequent measurements of assimilation rates in the field, greenhouse, and laboratory were conducted at PFD levels $>1000 \mu \mathrm{mol} \cdot \mathrm{m}^{-2} \cdot \mathrm{s}^{-1}$ to ensure light-saturating conditions. Maximum $A$ rates were measured at $\mathrm{g}_{\mathrm{s}}>256 \mu \mathrm{mol} \cdot \mathrm{m}^{-2} \cdot \mathrm{s}^{-1}$, whereas transpiration rate continued to increase until $\mathrm{g}_{\mathrm{s}}$ reached 380 $\mu \mathrm{mol} \cdot \mathrm{m}^{-2} \cdot \mathrm{s}^{-1}$ (Fig. 2). Temperature also influenced $\mathrm{CO}_{2}$ assimilation at $<16 \mathrm{C}$ and $>34 \mathrm{C}$ (Fig. 3). Within the range from 18 to $32 \mathrm{C}$, assimilation rates did not fluctuate significantly. High temperatures, $>34 \mathrm{C}$, resulted in a decline in assimilation rate concomitant with an increase in VPD. Subsequent gas exchange measurements in the field and greenhouse were made at ambient temperatures from 22 to $32 \mathrm{C}$.

In greenhouse-cultured plants, water use efficiency (WUE) decreased rapidly as VPD increased $>1 \mathrm{kPa}$ (Fig. 4a), but stabilized at a low level of WUE $\left(0.5 \mathrm{mmol} \cdot \mathrm{mol}^{-1}\right)$ when VPD was $1.5 \mathrm{kPa}$ or higher. The WUE of field-grown plants decreased less rapidly as a function of increasing VPD than did greenhouse plants, and did not reach $0.5 \mathrm{mmol} \cdot \mathrm{mol}^{-1}$ until VPD exceeded $3.5 \mathrm{kPa}$ (Fig. 4b). At all experimentally induced intercellular $\mathrm{CO}_{2}$ concentrations, assimilation rates in watered (nonstressed) plants were higher than those in stressed plants (Fig. $5 \mathrm{~A}$ and B). Maximum photosynthetic rate in nonstressed plants was reached at a $\mathrm{C}_{\mathrm{i}}$ of $\approx 150 \mu \mathrm{mol} \cdot \mathrm{mol}^{-1}$. In stressed plants, the $\mathrm{CO}_{2}$ compensation point was $\approx 100 \mu \mathrm{mol} \cdot \mathrm{mol}^{-1}$, twice that of nonstressed plants (Fig. $5 \mathrm{~A}$ and $\mathrm{B}$ ).

Drought-stressed greenhouse and field plants had $63 \%$ to $73 \%$ lower $\mathrm{CO}_{2}$ assimilation rates than well-watered plants. Stomatal conductances of drought-stressed plants averaged $\approx 85 \mu \mathrm{mol} \cdot \mathrm{m}^{-2} \cdot \mathrm{s}^{-1}$, which was $\approx 80 \%$ lower than $g_{s}$ in control plants (data not shown).

Plant water potential recovered rapidly and completely within $12 \mathrm{~h}$ after rewatering (Table 1 ). Recovery of photosynthesis from a water deficit condition following rewatering was rapid in cucumbers. The $A$ rate increased from 3.5 to $11.7 \mu \mathrm{mol} \cdot \mathrm{m}^{-2} \cdot \mathrm{s}^{-1}$ at $350 \mathrm{ppm}$ $\mathrm{CO}_{2}$ within only $12 \mathrm{~h}$ after rewatering (Table 1 ). Increasing ambient $\mathrm{CO}_{2}$ concentration from 150 to $350 \mu \mathrm{l} \cdot \mathrm{liter}^{-1}$ caused significant increases in $\mathrm{A}$ and in the calculated intercellular $\mathrm{CO}_{2}$ concentration.

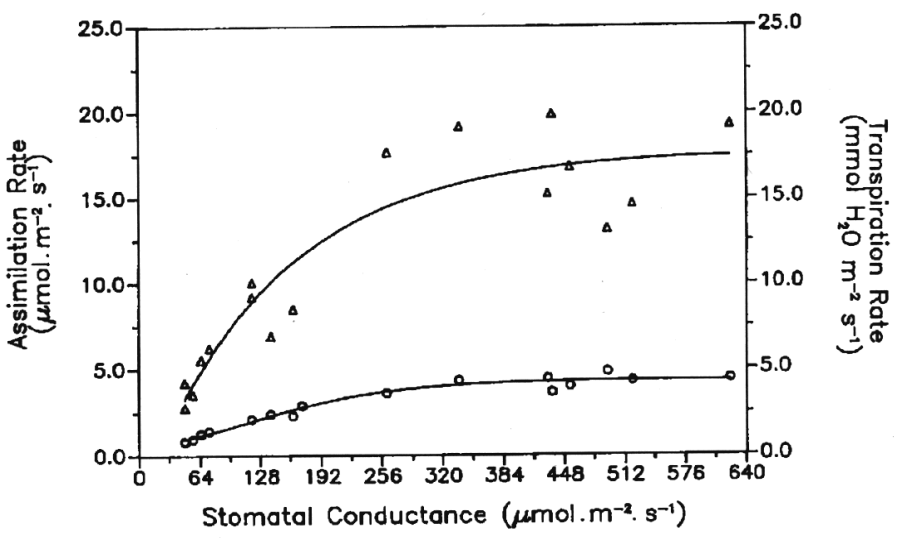

Fig. 2. Relationship between stomatal conductance and $\mathrm{CO}_{2}$ assimilation $(\mathrm{O})$ and transpiration rates $(\Delta)$ in well-watered greenhouse-grown cucumber plants. Data points represent individual measurements on cucumber leaves at the fifth node from the shoot apex. The curves were fitted according to the equation: $Y=B_{1} \times$ $\operatorname{Exp}\left(B_{2} \times X\right)+B_{3}$, where $B_{n}$ are estimated variables. The values of $r^{2}$ for the assimilation and transpiration curves were 0.86 and 0.97 , respectively. 


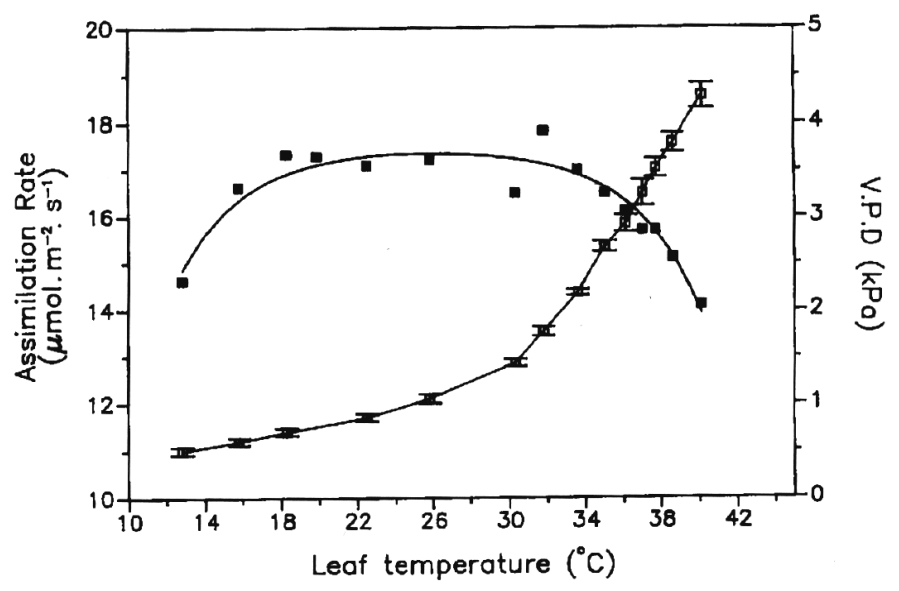

Fig. 3. Influence of temperature on $\mathrm{CO}_{2}$ assimilation rate in the fifth leaf from the shoot apex of well-watered greenhouse-grown cucumber plants ( $\square$ ). Corresponding vapor pressure deficit(VPD) ( $\square$ ) values at the time of measurement. VPD values are means of four measurements with vertical bars indicating the SE. A curve was fitted to the assimilation rate data using the equation: $Y=B_{1} /[1+$ $\left.\mathrm{B}_{2} \times \operatorname{Exp}\left(-\mathrm{B}_{3} \times \mathrm{X}+\mathrm{B}_{4} \times \mathrm{X}^{2}\right)\right]$, where $\mathrm{B}_{\mathrm{n}}$ are estimated variables; $r^{2}=0.90$.

The levels of sugars in young, fully expanded cucumber leaves were affected by water deficits. The concentration of sucrose in leaves of stressed fruiting plants $\left(1.03 \mathrm{mg} \cdot \mathrm{g}^{-1}\right.$ fresh weight $)$ was $\approx 300 \%$ higher than measured in leaves of well-watered plants (Table 2). Stachyose concentration in leaves of stressed fruiting plants was $30 \%$ lower than in leaves of nonstressed plants. The concentrations of raffinose and reducing sugars were similar in leaves of both types of plants.

\section{Discussion}

Studies on the effects of water deficits on photosynthesis have often reached different conclusions regarding the importance of low $\mathrm{C}_{\mathrm{i}}$ in limiting photosynthesis in drought-stressed plants (Ackerson and Hebert, 1981; Krieg and Hutmacher, 1986; Raschke and Hedrich, 1985; Thorne and Koller, 1974). However, it is generally accepted that a $\mathrm{CO}_{2}$ limitation is at least partially responsible for decreases in the $\mathrm{CO}_{2}$ assimilation rate in water-stressed plants.

In cucumber plants, we found that water deficits resulted in significant decreases in A and $g_{s}$. Our results indicated that $g_{s}<256$ $\mu \mathrm{mol} \cdot \mathrm{m}^{-2} \cdot \mathrm{s}^{-1}$ apparently limited $\mathrm{CO}_{2}$ availability and resulted in lower photosynthetic rates. However, the decrease in $A$ in water-stressed plants does not appear to be due solely to a decrease in $\mathrm{CO}_{2}$ availability. The initial slope of the $A / C_{i}$ relationship was altered by an internal plant water deficit that resulted in an apparent change in the $\mathrm{CO}_{2}$ compensation point for photosynthesis in drought-stressed plants (Fig. 5). The shift in $\mathrm{CO}_{2}$ compensation point to a higher value in stressed plants indicates that nonstomatal factors, possibly involving a change in the carboxylation efficiency of ribulosebisphosphate carboxylase (EC 4.1.1.39; RuBPcase), are contributing to the decrease in $A$ under water-limiting conditions.

These responses are consistent with the effects of ABA on leaf photosynthesis (Raschke and Hedrich, 1985); ABA is known to accumulate in leaves of drought-stressed plants and to directly affect stomatal aperture and photosynthetic $\mathrm{CO}_{2}$ fixation (Raschke and Hedrich, 1985). Vu and Yelenosky (1988) reported that the activity of extractable RuBPcase was relatively low in waterstressed orange [Citrus sinensis (L.) Osb.] plants. In contrast, Sharkey and Seemann (1989) found no evidence of damage to

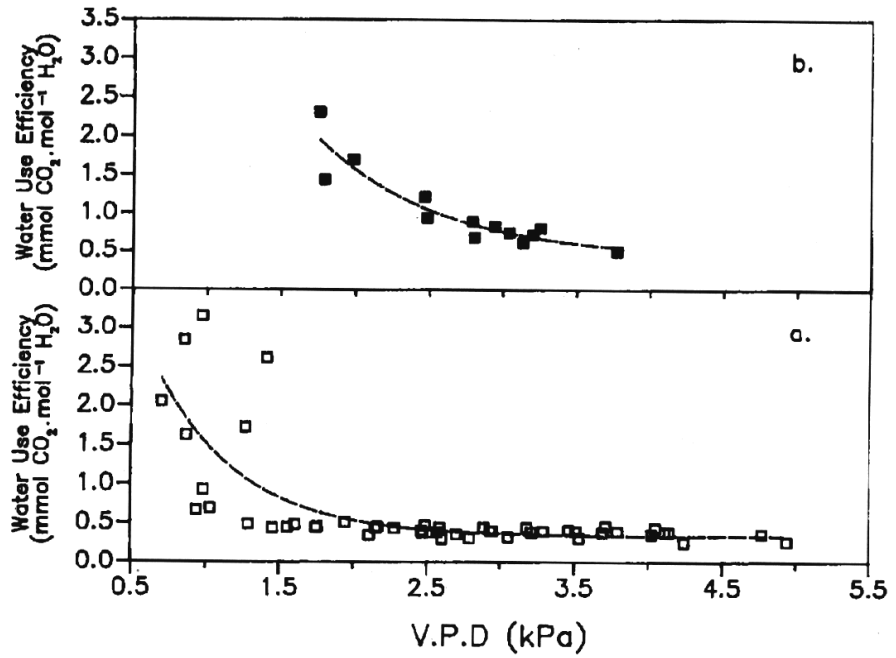

Fig. 4. Association of VPD with water-use efficiency of cucumber leaves from well-watered (a) greenhouse- $(\square)$ and (b) field- $(\square)$ cultured plants. Data points represent measurements on individual leaves. The curves were fitted according to the equation: $Y=B_{1} \times \operatorname{Exp}\left(B_{2} \times X\right)+B_{3}$, where $B_{n}$ are estimated variables. The value of $r^{2}$ for (a) and (b) was 0.89 and 0.86 , respectively.

chloroplast biochemical reactions and concluded that the decrease in photosynthetic rates of drought-stressed plants was the result of

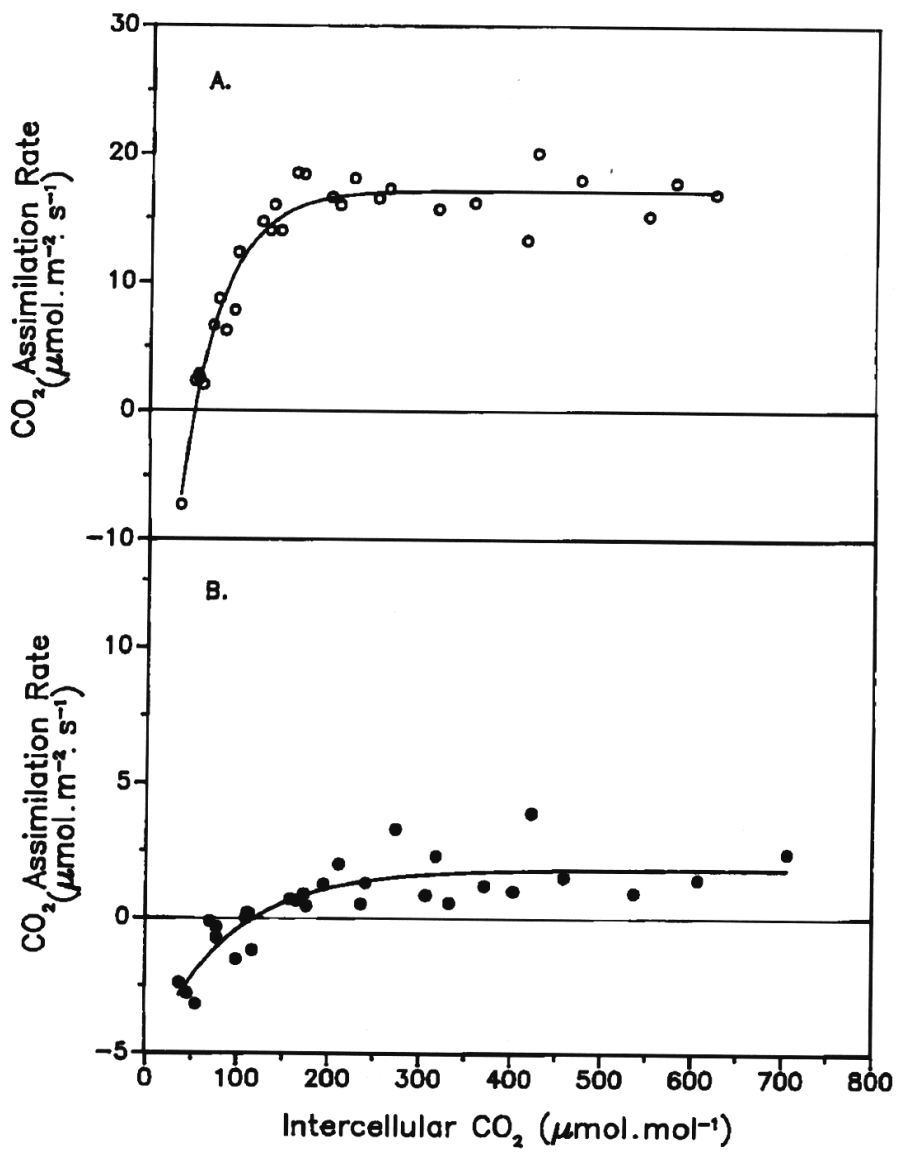

Fig. 5. Relationship between intercellular $\mathrm{CO}_{2}\left(\mathrm{C}_{\mathrm{i}}\right)$ assimilation rate in individual leaves of $(\mathbf{A})$ well-watered $(\mathrm{O})$ and $(\mathbf{B})$ water-stressed $(O)$ cucumber plants. $\mathrm{C}$ was calculated from gas exchange measurements according to the equations of Von Caemmerer and Farquhar (1981). Data points represent individual measurements. The curve was fitted according to the equation: $Y=B_{1} \times \operatorname{Exp}(B$ $\times \mathrm{X})+\mathrm{B}_{3}$, where $\mathrm{B}_{\mathrm{n}}$ are estimated variables; $r^{2}=0.94$ and 0.73 for well-watered and water-stressed plants, respectively. 
Table 1. Effects of water regime and ambient $\mathrm{CO}_{2}$ concentration on photosynthesis, water use efficiency (WUE), and water potential of cucumber leaves.

\begin{tabular}{|c|c|c|c|c|c|}
\hline \multirow[b]{3}{*}{ Water regime } & \multicolumn{3}{|c|}{$\begin{array}{c}\mathrm{CO}_{2} \text { assimilation rate } \\
\left(\mu \mathrm{mol} \cdot \mathrm{m}^{-2} \cdot \mathrm{s}^{-1} \pm \mathrm{SE}\right)\end{array}$} & \multirow{3}{*}{$\begin{array}{c}\text { WUE } \\
\left(\mathrm{mmol} \mathrm{CO}_{2} /\right. \\
\left.\mathrm{mol} \mathrm{H}_{2} \mathrm{O}^{-1}\right)\end{array}$} & \multirow{3}{*}{$\begin{array}{c}\text { Water } \\
\text { potential } \\
(\mathrm{MPa})\end{array}$} \\
\hline & \multicolumn{3}{|c|}{$\mathrm{CO}_{2}$ concn $^{2}$} & & \\
\hline & 150 & 250 & 350 & & \\
\hline Water withheld & $1.5 \pm 0.4$ & $2.3 \pm 0.3$ & $3.5 \pm 0.8$ & 4.3 & -0.77 \\
\hline Rewatered $^{\mathrm{x}}$ & $8.0 \pm 0.4$ & $11.0 \pm 1.2$ & $11.7 \pm 1.1$ & 5.1 & -0.10 \\
\hline Watered & $9.6 \pm 0.7$ & $11.2 \pm 1.2$ & $12.9 \pm 1.1$ & 4.1 & -0.08 \\
\hline
\end{tabular}

${ }^{\mathrm{z}}$ Ambient $\mathrm{CO}_{2}$ concentration, ppm.

${ }^{y}$ Water withheld until predawn leaf water potentials reached $-0.6 \mathrm{MPa}$.

${ }^{x}$ Gas exchange measured $12 \mathrm{~h}$ after rewatering of drought-stressed plants.

Table 2. Soluble sugar concentrations in recently fully expanded leaves from drought-stressed ${ }^{z}$ and well-watered cucumber plants during fruit development.

\begin{tabular}{lcccc}
\hline \hline & \multicolumn{4}{c}{$\left(\mathrm{mg} \cdot \mathrm{g}^{-1}\right.$ fresh $\left.\mathrm{wt} \pm \mathrm{SE}\right)$} \\
\cline { 2 - 5 } Water & Sucrose & Stachyose & Raffinose & $\begin{array}{c}\text { Reducing } \\
\text { sugars }\end{array}$ \\
regime & $1.03 \pm 0.14$ & $1.15 \pm 0.03$ & $0.12 \pm 0.03$ & $0.97 \pm 0.03$ \\
Stressed & $1.65 \pm 0.12$ & $0.13 \pm 0.07$ & $1.03 \pm 0.14$ \\
Well-watered & $0.33 \pm 0.03$ & &
\end{tabular}

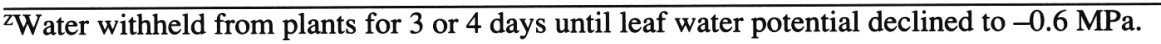

stomatal closure, which limited $\mathrm{CO}_{2}$ availability. However, an effect of the chloroplast environment, in situ, on enzyme activity cannot be precluded because both $\mathrm{Vu}$ and Yelenosky (1988) and Sharkey and Seemann (1989) assayed only extractable enzyme activities. Berkowitz and Gibbs (1983) reported that photosynthesis was inhibited at low osmotic potentials associated with plant-water deficit conditions due to stromal acidification, which inhibited the activity of frucrose-1,6-biphosphatase.

Higher concentrations of sucrose and were detected in leaves of water-stressed cucumber plants than in nonstressed plants. Although gas exchange measurements and sugar determinations were made on different leaves, these observations are in agreement with the findings of Azcon-Bieto (1983) and Thorne and Koller (1974), who attributed the decrease in photosynthesis in droughtstressed plants to feedback inhibition resulting from photoassimilate accumulation.

The adverse effects of water deficits on photosynthesis were reversible. When water stress was relieved, recovery of photosynthetic activity was rapid, occurring within $12 \mathrm{~h}$ of rewatering. For complete and rapid recovery of photosynthesis, the adverse effects of water stress on both stomatal and nonstomatal factors must also be reversible within a short period after stress is relieved. In our study, photosynthesis recovered, although stomatal conductance did not recover completely following rewatering (data not shown). Incomplete stomatal recovery may have resulted from the accumulation of ABA in leaves of water-stressed plants (Ackerson, 1980; Eze et al., 1983; Raschke and Hedrich, 1985) at levels sufficiently high to prevent complete stomatal opening. ABA sensitizes stomata to $\mathrm{CO}_{2}$, leading to stomatal closure at lower $\mathrm{C}_{\mathrm{i}}$ levels (Raschke and Hedrich, 1985). RuBPcase activity has been reported to recover partially within 1 day after stress is relieved $(\mathrm{Vu}$ and Yelenosky, 1988), suggesting that enzymatic activity might be regained within hours after plant rehydration.

In this study, stachyose, the predominant translocate sugar in cucurbits (Pharr et al., 1985; Richardson et al., 1982;), was present at relatively low concentrations in leaves of stressed plants as compared to well-watered plants. Low stachyose accumulation could be attributed to either low rates of stachyose biosynthesis or rapid export from leaves. Phloem export rates of stachyose, however, would be expected to be low under water deficit conditions, due to an inhibitory effect of low-water potentials on turgor development within the sieve tube-companion cell complex (Sung and Krieg, 1979), even though stachyose synthase activity is localized within intermediary cells in minor veins (Holthaus and Schmitz, 1991). We postulate that a reduction in sink activity may have a feedback inhibitory effect on stachyose synthesis within source leaf tissue. Defruiting of cucumber plants was found to result in significantly $(P<0.05)$ lower stachyose concentrations in leaf tissue (1.03 $\mathrm{mg} \cdot \mathrm{g}^{-1}$ fresh weight) as compared to that in fruiting plants of similar age $\left(1.65 \mathrm{mg} \cdot \mathrm{g}^{-1}\right.$ fresh weight $)$ under well-watered conditions (Widders, unpublished data). This difference occurred in spite of the fact that defruiting also lowers assimilate export from leaves (Barrett and Amling, 1978). The cause of a decrease in stachyose synthesis under low intercellular water potentials is not evident, but apparently was not due to a limitation in availability of precursors, sucrose, and raffinose (Table 2).

The decreases that we observed in $\mathrm{CO}_{2}$ assimilation rates in stressed plants were probably not a result of a high temperature effect on photosynthesis. Temperatures in the range of 16 to $34 \mathrm{C}$ had no apparent effect on $A$ in cucumber plants. However, leaf temperature, under water deficit conditions in the field, might exceed 34C if transpiration rates were low. The specific effect of high temperatures $(>34 \mathrm{C})$ on leaf photosynthesis could not be determined because of the associated increase in VPD, which probably induced stomatal closure. Thus, stomatal closure may have contributed to the decline in photosynthetic rate at high temperature.

Water use efficiency was influenced by environmental factors and growing conditions. WUE decreased rapidly as the leaf-air VPD increased, which is in agreement with other reports (Cock et al., 1985). An increase in VPD would induce stomatal closure (Schulze and Hall, 1982), thus limiting $\mathrm{CO}_{2}$ availability and ultimately reducing photosynthesis (Raschke and Hedrich, 1985). Concurrently, the increase in VPD leads to an increase in transpiration, which reduces the WUE. Comparison of the WUE-to-VPD relationship between greenhouse- and field-grown cucumber plants 
(Fig. 4) indicates that, at VPD between 1.5 and $3.0 \mathrm{kPa}$, fieldgrown plants had higher WUE than greenhouse-grown plants. Leaves that develop on plants under stress-inducing conditions of high temperature, low soil moisture or high irradiance, characteristic of environmental conditions in the field, have smaller cells (Yegappan et al., 1982) due to less expansive growth. Such leaves typically will have a higher WUE (Nobel, 1980). The same reasoning can be used to explain the higher WUE observed in drought-stressed, greenhouse-grown cucumber plants as compared to irrigated plants.

In summary, our results indicate that the effects of water deficits on photosynthesis in cucumber plants cannot be explained solely by the observed decrease in stomatal conductance and intercellular $\mathrm{CO}_{2}$ concentrations in drought-stressed cucumber plants. The results of this study also indicate that photosynthesis in cucumber plants is capable of rapid recovery from transient mild water deficits without apparent long-term adverse effects.

\section{Literature Cited}

Ackerson, R.C. 1980. Stomatal responses of cotton to water stress and abscissic acid as affected by water stress history. Plant Physiol. 65:455459.

Ackerson, R.C. and R.R. Hebert. 1981. Osmoregulation in cotton in response to water stress. I. Alterations in photosynthesis, leaf conductance, translocation and ultrastructure. Plant Physiol. 67:484-488.

Azcon-Bieto, J. 1983. Inhibition of photosynthesis by carbohydrates in wheat leaves. Plant Physiol. 73:681-686.

Barrett, J.E., III and H.J. Amling. 1978. Effects of developing fruit production and translocation of ${ }^{14} \mathrm{C}$-labeled assimilates in cucumber. HortScience 13:545-547.

Berkowitz, G.A. and M. Gibbs. 1983. Reduced osmotic potential effects on photosynthesis. Identification of stomatal acidification as a mediating factor. Plant Physiol. 71:905-911.

Blackman, P.G. and W.J. Davies. 1985. Root to shoot communication. J. Expt. Bot. 36:39-48.

Cock, J.H., M.C.M. Porto, and M.A. El-Sharkawy. 1985. Water use efficiency of cassava. III. Influence of air humidity and water stress on gas exchange of field grown cassava. Crop Sci. 25:265-272.

Doss, B.D., C.E. Evans, and J.L. Turner. 1977. Irrigation and applied nitrogen effects on snap beans and pickling cucumbers. J. Amer. Soc. Hort. Sci. 102:654-657.

Elkner, K. 1985. The influence of different moisture contents and nitrogen levels on the formation of empty cavities in cucumbers (Cucumis sativus L.). Acta Agrobotanica 35:61-68.

Eze, J.M.O., E.B. Dumbroff, and J.E. Thompson. 1983. Effects of temperature and moisture stress on the accumulation of abscisic acid in bean. Physiol. Plant. 58:179-183.

Genty, B., J.M. Briantais, and J.B. Dasilva. 1987. Effects of drought on primary photosynthetic processes of cotton leaves. Plant Physiol. 83:360-364.

Holthaus, U. and K. Schmitz. 1991. Distribution and immunolocalization of stachyose synthase in Cucumis melo L. Planta 185:479-486.
Huck, M.G., K.I. Ishihara, C.M. Peterson, and T. Ushijima. 1983. Soybean adaptation to water stress at selected stages of growth. Plant Physiol. 73:422-427.

Karamanos, A.J., J. Elston, and R.M. Wadsworth. 1982. Water stress and leaf growth of field beans (Vicia faba L.) in the field: Water potentials and laminar expansion. Ann. Bot. 49:815-826.

Krieg, D.T. and R.B. Hutmacher. 1986. Photosynthetic rate control in sorghum (Sorghum bicolor). Stomata1 and non-stomatal factors. Crop Sci. 26:112-117.

Loomis, E.L. and P.C. Crandall. 1977. Water consumption of cucumbers during vegetative and reproductive stages of growth. J. Amer. Soc. Hort. Sci. 102:124-127.

Moon, J.W. and J.A. Flore. 1986. A basic computer program for calculation of photosynthesis, stomatal conductance and related parameters in an open gas exchange system. Photosyn. Res. 7:269-279.

Nobel, P.S. 1980. Leaf anatomy and water use efficiency, p. 43-55. In: C. Turner and P.J. Kramer (eds.). Adaptation of plants to water and high temperature stress. Wiley, New York.

Pharr, D.M., S.C. Huber, and H.N. Sox. 1985. Leaf carbohydrate status and enzymes of translocate synthesis in fruiting and vegetative plants of Cucumis sativus L. Plant Physiol. 77:104-108.

Raschke, K. and R. Hedrich. 1985. Simultaneous and independent effects of abscisic acid on stomata and the photosynthetic apparatus in whole leaves. Planta 163:105-118.

Richardson, P.T., D.A. Baker, and L.C. Ho. 1982. The chemical composition of cucurbit vascular exudates. J. Expt. Bot. 33:1239-1247.

Sams, C.E. and J.A. Flore. 1982. The influence of age, position and environmental variables on net photosynthetic rate of sour cherry leaves. J. Amer. Soc. Hort. Sci. 107:339-344.

Schulze, E.D. and A.E. Hall. 1982. Stomatal responses, water loss and $\mathrm{CO}_{2}$ assimilation rates of plants in contrasting environments. Physiological plant ecology II. Water relations and carbon assimilation, 12B:181-231. In: Encyclopedia Plant Physiol. Springer-Verlag, Berlin.

Schulze, E.D. and M. Kuppers. 1979. Short term and long term effects of plant water deficits on stomatal responses to humidity in Corylus avellana L. Planta 146:319-326.

Sharkey, T.D. and J.R. Seemann. 1989. Mild water stress effects on carbon-reduction-cycle intermediates, ribulose bisphosphate carboxylate activity, and spatial homogeneity of photosynthesis in intact leaves. Plant Physiol. 89:1060-1065.

Sung, F.J.M. and D.R. Krieg. 1979. Relative sensitivity of photosynthetic assimilation and translocation of ${ }^{14}$ carbon to water stress. Plant Physiol. 64:852-865.

Thorne, J.H. and H.R. Koller. 1974. Influence of assimilate demand on photosynthesis, diffusive resistance, translocation and carbohydrate levels of soybean leaves. Plant Physiol. 54:210-217.

Von Caemmerer, S. and G.D. Farquhar. 1981. Some relationships between the biochemistry, photosynthesis and the gas exchange of leaves. Planta 153:376-387.

Vu, J.C.V. and G. Yelenosky. 1988. Water deficit and associated changes in some photosynthetic parameters in leaves of 'Valencia' orange (Citrus sinensis L. Osbeck). Plant Physiol. 88:375-378.

Yegappan, T.M., D.M. Paton, C.T. Gates, and W.J. Muller. 1982. Water stress in sunflower (Helianthus annuus L.) 2. Effects on leaf cells and leaf area. Ann. Bot. 49:63-68. 